\title{
Ulayat Rights in A Human Rights Perspective
}

\author{
Zahroni $^{1}$, Faisal Santiago ${ }^{2}$ \\ Borobudur University ${ }^{1,2}$ \\ \{zahroniunboro@gmail.com ${ }^{1}$, faisalsantiago@borobudur.ac.id $\left.{ }^{2}\right\}$
}

\begin{abstract}
Indonesia consists of many tribes that have customary laws in them. Customary rights for indigenous peoples often intersect with their use for the state. Legal protection for holders of customary matters, especially for the Kadorih Dayak indigenous people, is important to be investigated. By using a normative approach, through extracting library data and field data it is found that the protection of customary rights is still normative and has not been properly implemented. There have been attempts to marginalize indigenous peoples without a constructive solution from the state. Efforts are needed to raise awareness of the protection of customary rights law, as a form of respect and recognition of indigenous peoples as equal parts of Indonesian society before the law.
\end{abstract}

Keywords: Customary Rights; Dayak Kadorih; Human Rights

\section{Introduction}

The number of tribes that inhabit the territory of Indonesia makes this country one of the countries with an extraordinary wealth of human resources. The cultural wealth is one of the important assets in the life of the nation and state. Cultural diversity is important for the development and advancement of human resources. Each culture belongs to the tribes in the territory of the Unitary State of the Republic of Indonesia, and each tribe has its customary territory and applicable customary law. Customary diversity requires good diversity management.

The number of customs in this country requires good handling, related to conventional laws which vary widely from one indigenous community to another. One part that needs to be handled properly is the issue of customary land. Each tribe or customary community has customary land which is highly guarded and preserved by the local community. Customary land owned by the community is protected by local customary law, and usually has different regulations or laws governing customary territories from one another. This diversity of laws causes frequent disputes between indigenous peoples and individuals and companies.

Conflicts or customary disputes that occur are often caused by a lack of understanding between indigenous peoples and communities or companies that intend to manage or own land in customary land areas. The existing phenomenon shows that when a dispute occurs, the state is present as an intermediary who makes resolutions to the conflicts that occur.[1] The state that is present as an intermediary uses state law to be able to regulate and resolve existing conflicts. However, the state often fails to handle conflicts that occur when it comes to 
communities and customary lands.[2] This stuttering is a proof that the understanding of customary law has not been properly understood by the existing officials and stakeholders.

For indigenous peoples, land is a vital object and has transcendental meaning for the local community.[3] It is this transcendental meaning of land that is often unknown to residents outside the culture and customs of the local community. This is what is often used as an offense for immigrants who want to control land in local customary territories. For the general public, the land is interpreted in terms of production and economy only. This gap often triggers conflicts between indigenous peoples and residents or individuals as well as with companies.

This sacred and economic value has been bridged by the founder of the Unitary State of the Republic of Indonesia and stated in the 1945 Constitution, especially in article 33 paragraph (3) which states that Earth, Water, and the Natural Resources contained therein are managed by the State and are used as much as the amount for the prosperity of the people. The state has guaranteed the prosperity of the people through what is on earth and Indonesia's natural resources, including indigenous peoples. However, it is factually found that the implementation of the 1945 Constitution has not been fully implemented properly. Ownership of land by entrepreneurs has entered the territory of customary land so that often conflicts or disputes occur between indigenous peoples and companies.

Disputes that pop up to the public usually have entered the realm of law, however, disputes at the grassroots are rarely highlighted by the media. One of the indigenous peoples in dispute with the company is the Kadorih Dayak tribe with a mining company in the Central Kalimantan region. Indigenous people who feel that their customary land is being disturbed staged a protest at the company because the company passed through their customary land for transportation to the company's territory. On the other hand, the company began negotiating through government officials to immediately evict and shift the customary land to become company property. Until now, the conflict has not been resolved properly, if there are triggers then clashes will arise and things that are not desirable.

Seeing this phenomenon, how is the protection of customary rights for indigenous peoples? The indigenous peoples, in this case, the Kadorih Dayak tribe, are Indonesian citizens who inhabit the territory of the Unitary State of the Republic of Indonesia and deserve to be guaranteed their rights to their territory. From the perspective of human rights, how can these customary rights be protected by law in the country of Indonesia? Furthermore, this paper will describe the problems mentioned above.

\section{Research Method}

This study uses a normative research method that is used to investigate and resolve problems in depth related to customary rights from a human rights perspective. Data mining will be used through the literature and accompanied by data obtained from the field, [4] particularly concerning the Kadorih Dayak tribe in Central Kalimantan. The data obtained will then be analyzed descriptively so that it can be presented comprehensively.

\section{Discussion}

Communal land contact with the general public or companies is often the cause of horizontal conflict.[1] This conflict can be minimized when philosophically understanding the 
legal protection of land used for the benefit of community welfare. Article 33 paragraph (3) of the 1945 Constitution becomes the basis for legal protection for the community. A statement that affirms that the land and water and natural resources are controlled by the state for the welfare of the people becomes legal protection for individuals or companies who want to control land in Indonesian territory only for their interests.

The 1945 Constitution is the basis for derivative regulations governing customary land. The government provides a derivative of regulations regarding agrarian into the Basic Agrarian Law Number 5 of 1960. In this law, rights to land and natural resources are regulated in article 2. It regulates the subject:

a. Manage and administer the designation, use, supply, and maintenance.

b. Determine and regulate the rights that can be had on (part of) the earth, water, and space.

c. Determine and regulate legal relationships between people and legal actions concerning the earth, water, and space.

d. Everything to achieve the greatest prosperity of the people in the framework of a just and prosperous society.

In the Basic Agrarian Law Number 5 of 1960, there is a clause which states that "... the state controls ..." means that the state has the right to control agrarian resources. However, in that sense, it means that the control by the state is only controlling so that it can be managed for the prosperity and welfare of the community.[5] Control by the state occurs when the state needs the land for the benefit of the wider community. However, the rights to the land remain with the owner, namely the customary community or individuals who control it. In this case, the state only acts as a legal entity that covers, manages, and regulates the existing land.[6]

Concerning customary land, indigenous peoples have customary laws to regulate the life order in their territories. This customary law regulates customary land which becomes territory land for these customary communities. The relationship between state law and customary law is regulated in the Basic Agrarian Law Number 5 of 1960. In this law, it is regulated that state law coexists with customary law in regulating and realizing prosperity and welfare in society. [7] The harmonious relationship between state law and customary law creates a balance of applicable laws, especially for indigenous peoples.

Customary land which is regulated in customary law gives rise to rules regarding territory land and territory rights. Concerning territory land, there are two parts of territory land which later become ulayat rights. The first territory land is an individual right that is passed from generation to generation. The land is managed and preserved by individuals. If the customary land belonging to individuals is formalized into state law, then its traditionality will be lost, because it has been handed over to the state. The second part is territory land owned by indigenous peoples. Ulayat lands owned by indigenous peoples are the ulayat rights of all local customary communities. In practice, the customary rights owned by all customary communities are handed over to the customary head or traditional elders as representatives of the indigenous peoples to manage, care for and preserve them. If there are problems related to township land owned by the customary community, even though it can be seen that the customary head or traditional elder is in front, the adat community is ready to fully support the decision of the local customary leader. [8]

Referring to the Basic Agrarian Law Number 5 of 1960, that customary law has a place in state law, so the territory land owned by the customary community has legal force recognized by the state. If there is a denial of customary land and customary law, then it violates the prevailing laws, especially the Basic Agrarian Law Number 5 of 1960. Communities outside of customary territories often do not know about customary law and the existence of customary rights in indigenous peoples, so that the general public and the company consider 
that the land is state land that can be privatized. This is often a trigger point for conflicts between indigenous peoples and the general public or companies.

The UN Declaration on 29 June 2006 agreed on the Rights of Indigenous Peoples / Indigenous Peoples. In it, there is an agreement on an important basis for the protection, recognition, and fulfillment of the rights of indigenous peoples. This declaration recognizes indigenous peoples who have the right to self-determination in their territories, about their cultural identity, education, language, health, and community management, as well as rights to land and development thereon. This declaration is related to international human rights instruments concerning people's rights and economic rights. International Human Rights provides a recognition related to the socio-culture of the community in which there are customary rights and indigenous peoples. The local government must take positive actions to protect, respect, recognize and fulfill customary rights to indigenous peoples / indigenous people in the territory of the local state. Violation of these provisions and agreements is categorized as a violation of the law. Indonesia is one of the countries that signed the declaration and has the mandate to adopt it into Indonesian law.

The founders of the state have adopted and facilitated customary law and indigenous peoples in the 1945 Constitution, especially in article 18B paragraphs 1 and 2. The law states:

a. The state recognizes and respects units of regional government which are special or special in nature which is regulated by law.

b. The state recognizes and respects customary law communities and their traditional rights as long as they are still alive and under community development and the principles of the Unitary State of the Republic of Indonesia as regulated in the Law.

These laws and regulations state that the Indonesian state gives recognition and respect to indigenous peoples along with their inherent traditional rights. However, it must be remembered that there are things that must be considered related to the requirements recorded in the law so that recognition of customary law can be accommodated by the state, namely:
a. Throughout Still Life
b. Following the development of society
c. Under the principles of the Republic of Indonesia
d. Regulated in law

In many statutory analyzes, this requirement is a limitation from the government and in an attempt to make customary law into positive law or national law.[9] Such requirements are discriminatory requirements because they are closely related to the existence of culture. [10] It can be seen that the existing law is inconsistent so that confusion and stuttering often occur in its implementation to the community.

Concerning the protection of customary rights for the Kadorih Dayak tribe, the prevailing laws and regulations provide legal guarantees that the state guarantees in the development of the life of the nation and state. The customary rights owned by the indigenous people of the Kadorih Dayak tribe need to be fought for because they are guaranteed and protected from the laws in force in Indonesia. The prevailing legislation is a strong guarantee, starting from the 1945 Constitution, the Basic Agrarian Law, to International Human Rights, ensuring protection for the development and development of indigenous peoples.

The dispute that occurred was basically ignorance regarding the customary rights that exist in the indigenous Dayak Kadorih tribe. The company and the officials handling the conflict do not know and do not understand customary rights and the legal provisions that cover them. The customary rights of the Daya Kadorih tribe are protected by international human rights. The existing officials and stakeholders need to understand this regulation so that conflicts can be unraveled and resolved properly. The consistency and consequences of law enforcement by 
the government on customary rights protected by human rights have made the trust and welfare of indigenous peoples well protected by the Indonesian government.

The wrong handling and resolution of conflicts over customary rights by the government that is not based on the applicable regulations will lead to marginalization and discrimination of indigenous peoples. A good understanding of human rights, especially regarding customary rights for indigenous peoples, needs to be performed properly among the existing officials and stakeholders, as a step in realizing the ideals of the nation's founder, namely a wealthy and prosperous society.

\section{Conclusion}

Legal protection for holders of customary land over customary land has been stated in the 1945 Constitution and its derivatives in the Basic Agrarian Law Number 5 of 1960. Internationally, the Unitary State of the Republic of Indonesia participates in the signing of a declaration related to International Human Rights in its efforts to protect the community. native or indigenous people in the territory. This legal protection affirms that the customary rights that exist within the customary community have been guaranteed and protected by existing laws and regulations in Indonesia. The commitment and efforts of the Unitary State of the Republic of Indonesia in protecting and guaranteeing customary rights as part of indigenous peoples is a good first step towards realizing a prosperous and prosperous society. However, the initial steps in the form of existing laws and regulations need to be accompanied by good implementation and law enforcement under applicable rules. Good implementation efforts accompanied by constructive conflict resolution efforts are a form of respect and recognition of indigenous peoples as equal parts of Indonesian society before the law.

\section{References}

[1] L. Rahayu, "Problematika Penyelesaian Konflik Tanah Ulayat Masyarakat Adat Di Kabupaten Kampar," Jur. Ilmu Pemerintah. Fak. Ilmu Sos. dan Ilmu Polit. Univ. Riau, pp. 1-14, 2013.

[2] S. Anas, S. F. Dewi, and J. Indrawadi, "Faktor Penyebab Konflik Tanah Ulayat Antara Peladang Pendatang Vs Masyarakat Adat Di Desa Tamiai Kabupaten Kerinci," J. Sosiol. Reflektif, vol. 14, no. 1, p. 131, 2019, doi: 10.14421/jsr.v14i1.1702.

[3] S. Supriyanto, "IMPLEMENTASI KEBIJAKAN PERTANAHAN NASIONAL," $J$. Din. Huk., vol. 8, no. 3, Sep. 2008, doi: 10.20884/1.jdh.2008.8.3.78.

[4] M. Abdul Kadir, "Hukum Dan Penelitian Hukum.," Bandung PT. Citra Aditya Bakti., 2015.

[5] D. A. Widowati, A. N. Luthfi, and I. G. N. Guntur, Pengakuan dan Perlindungan Hak atas Tanah Masyarakat Hukum Adat di Kawasan Hutan. 2014.

[6] P. K. T. PATI, "IZIN PEMANFAATAN HUTAN DI ATAS HAK ULAYAT MASYARAKAT HUKUM ADAT DAYAK PUNAN ADIU DI KABUPATEN MALINAU PROVINSI KALIMANTAN UTARA SETELAH KELUARNYA PUTUSAN MAHKAMAH KONSTITUSI NOMOR 35/PUU-X/2012,” Yogyakarta, 2020.

[7] B. Harsono, Hukum Agraria Indonesia, Sejarah Pembentukan Undang-Undang Pokok Agraria, Isi dan Pelaksanaannya. Jakarta: Djambatan, 1999. 
[8] Afrizal, Sosiologi Konflik Agraria: Protes-Protes Agraria dalam Masyarakat Kontemporer. Andalas: University Press, 2006.

[9] R. Simarmata, Pengakuan Hukum Terhadap Masyarakat Adat di Indonesia. Jakarta: UNDP, 2006.

[10] M. R. Maramis, "KAJIAN ATAS PERLINDUNGAN HUKUM HAK ULAYAT DALAM PERSPEKTIF HAK ASASI MANUSIA,” vol. XXI, no. 4, pp. 98-110, 2013. 